ks. Kazimierz Panuś

\title{
Sprawozdanie prezesa Polskiego Towarzystwa Teologicznego za rok 2008
}

Poprzednie walne zebranie Polskiego Towarzystwa Teologicznego odbyło się 20 lutego 2008 roku. Obejmowało ono część sprawozdawczą za rok 2007, udzielenie absolutorium zarządowi i wybory nowych władz towarzystwa na trzyletnią kadencję. W drugiej części walnego zebrania wręczono medal Zasłużony dla Polskiego Towarzystwa Teologicznego ks. prof. dr. hab. Stefanowi Koperkowi CR i o. dr. Franciszkowi Małaczyńskiemu OSB.

\section{Stan towarzystwa}

Rok 2008 był pierwszym rokiem działalności zarządu wybranego 20 lutego 2008 roku. Działał on w roku sprawozdawczym w następującym składzie:

ZARZĄD

Prezes: ks. prof. zw. dr hab. Kazimierz Panuś

Wiceprezes: ks. dr hab. Roman Kuligowski, prof. UKSW

Sekretarz: ks. mgr Kazimierz Moskała

Skarbnik: ks. dr Andrzej Mojżeszko

Bibliotekarz: ks. dr hab. Jan Bednarczyk

Kierownik Sekcji Wydawniczej: mgr Sebastian Wojnowski

KOMISJA REWIZYJNA

Przewodniczący: ks. prof. zw. dr hab. Tomasz Jelonek

Członkowie: ks. dr Sylwester Jędrzejewski SDB, ks. dr Alfred Kardas CR

SĄD KOLEŻEŃSKI

Przewodniczący: ks. prof. zw. dr hab. Stefan Koperek

Członkowie: ks. dr Józef Rapacz, ks. dr Robert Tyrała

Z końcem roku 2007 Polskie Towarzystwo Teologiczne liczyło 699 członków. W roku sprawozdawczym przyjęto do towarzystwa 18 osób. Od ostatniego walnego zebrania do wieczności odeszli (według posiadanych informacji): ks. prałat Czesław Świniarski, ks. Adam Gacek, ks. Antoni Pawlita, Aldona Piller oraz ks. prof. dr hab. Zdzisław Kliś, kierownik Sekcji Sztuki Sakralnej. 


\section{Działalność towarzystwa}

Spełniając wymogi statutowe, zarząd odbył w roku sprawozdawczym cztery zebrania w dniach: 23 kwietnia 2008, 24 września 2008, 25 listopada 2008, 24 lutego 2009.

Podczas pierwszego zebrania zarząd powołał kierowników sekcji specjalistycznych i oddziałów terenowych na nową kadencję. Omówiono stan przygotowania sesji naukowej nt. Przebaczamy i prosimy o przebaczenie (część I), zaprezentowano i zatwierdzono projekt nowej okładki kwartalnika „Ruch Biblijny i Liturgiczny”. Przyjęto także propozycję, aby zebrania zarządu rozpoczynać dwudziestominutowym referatem podejmującym aktualne problemy z życia Kościoła.

Podczas drugiego zebrania zarządu wysłuchano referatu ks. dr. Bogusława Mielca nt. Język, jakim polskie media opisują Kościół, podsumowano konferencję naukową Przebaczamy i prosimy o przebaczenie oraz omówiono przygotowania do II sesji poświęconej problemowi przebaczenia. Zarząd zapoznał się z programem sesji naukowej nt. Świętość a dobro i powierzył prowadzenie Sekcji Teologii Życia Wewnętrznego (po wyjeździe ks. dr. Jana Nowaka do Kazachstanu) ks. dr hab. Wojciechowi Misztalowi, prof. PAT.

Trzecie zebranie zarządu rozpoczął wykład ks. prof. Janusza Królikowskiego nt. Zasady politeizmu w mediach - nowe wyzwanie. Zarząd zapoznał się ze sprawozdaniami z trzech konferencji naukowych: Świętość a dobro, Z dziejów kościoła św. Anny w Krakowie oraz z okazji 100-lecia urodzin prof. Juliana Aleksandrowicza. Wiceprezes ks. Roman Kuligowski omówił założenia nowego trzyletniego programu prac towarzystwa nt. teologii kultury (lata 2011-2013); ustalono termin oraz program walnego zebrania na dzień 24 lutego 2009 roku.

Czwarte przewidziane statutem zebranie zarządu odbyło się w dniu walnego zebrania. Zostało poświęcone planom powstania nowych oddziałów terenowych w Płocku, Toruniu, Legnicy, Sosnowcu i Szczecinie, stronie internetowej oraz tegorocznym konferencjom naukowym organizowanym przez Polskie Towarzystwo Teologiczne.

W ramach Polskiego Towarzystwa Teologicznego działa Studium Syndonologiczne, 15 sekcji specjalistycznych, 11 oddziałów terenowych i Sekcja Wydawnicza prowadząca Wydawnictwo UNUM.

Studium SyndonologiczNe. Moderatorem studium jest ks. doc. dr hab. Jerzy Chmiel. Studium Syndonologiczne służyło konsultacją dla zainteresowanych naukowców. Członek studium mgr inż. Jerzy Dołęga-Chodasiewicz z Kielc wygłosił szereg konferencji w wielu miejscowościach Polski, a lek. 
med. Bolesław Leonhard prowadził własne badania nad Całunem Turyńskim, których wynikami dzielił się z zainteresowanymi.

Sekcja Biblijna. Kierownikiem sekcji jest ks. dr hab. Roman Bogacz. W roku sprawozdawczym sekcja odbyła dwa spotkania. Pierwsze miało miejsce w dniu 21 października 2008 w krakowskim klasztorze Kapucynów z wykładem ks. prof. Tomasza Jelonka nt. Św. Pawet i jego nauka w nauczaniu Ojca Świętego Benedykta XVI. Podjęto także dyskusję nad kształtem czasopisma „Ruch Biblijny i Liturgiczny” i możliwościami włączenia Sekcji Biblijnej w jego prace. Proponowano zamieszczanie aktualnych informacji z wykopalisk prowadzonych w Ziemi Świętej oraz o przeprowadzonych przewodach doktorskich i habilitacyjnych, o konferencjach i innych pracach z zakresu biblistyki. Drugie spotkanie Sekcji Biblijnej poświęcone było polemice $z$ tezą dra Piotra Sikory, że w czasach eschatologicznych nastąpi wprost zniknięcie, ujednolicenie chrześcijan z Bogiem bądź z Jezusem Chrystusem. We wprowadzeniu do dyskusji ks. dr Stanisław Wronka przeprowadził wnikliwą analizę terminów greckich występujących w wybranych tekstach Nowego Testamentu, określających upodobnienie chrześcijan do Chrystusa w czasach eschatologicznych. Wykazał następnie, że istnieją dwie grupy terminów. Jedne odnoszą się do podobieństwa ludzi z Chrystusem bądź z Bogiem. Drugie natomiast wykazują zjednoczenie Chrystusa z Ojcem. Terminy te wyraźnie wskazują na różnicę, jaka zachodzi pomiędzy relacją człowiek-Chrystus czy człowiek-Bóg a relacją Chrystus-Bóg, SynOjciec. W tej drugiej relacji wyraźnie jest mowa o takim podobieństwie, które wskazuje na tożsamość, na równość. Dalszy ciąg spotkania wypełniła dyskusja na temat istoty podobieństwa zachodzącego między człowiekiem a Chrystusem czy też człowiekiem a Bogiem.

SeKcja Teologi Fundamentalnej. Kierownikiem sekcji jest ks. dr Józef Morawa. Sekcja nie zorganizowała w tym roku posiedzenia naukowego.

Sekcja Historyczna, której pracami kieruje ks. dr hab. Józef Marecki, prof. PAT, odbyła 6 spotkań tematycznych (dwory, zamki i pałace), w tym dwa wyjazdowe (Nowy Sącz, Legnica). Odbyły się też dwa spotkania zespołu badawczego heraldyki kościelnej poświęcone omówieniu herbów biskupów polskich mianownaych w latach 2007-2008. Sekcja współuczestniczyła w rganizacji kilku konferencji i imprez popularyzyjących naukę.

Sekcja Teologir Moralnes. Sekcję prowadzi ks. dr Bogusław Mielec. Na spotkaniu 2 października 2008 omówiono założenia sympozjum poświęconego upamiętnieniu 40. rocznicy encykliki Humanae vitae papieża Pawła VI. Sympozjum na ten temat odbyło się 11 grudnia 2008 w budynku Wyższego Seminarium Duchownego Archidiecezji Krakowskiej. W jego trakcie wygłoszono 3 referaty: Udziat kard. Karola Wojtyly i krakowskich 
teologów w przygotowaniu i recepcji encykliki. Próba syntezy w świetle materiatów archiwalnych (ks. dr Bogusław Mielec, Papieska Akademia Teologiczna w Krakowie), Reinterpretacja encykliki w świetle katechez środowych Jana Pawia II „Mężczyzna i niewiasta stworzyt ich” (o. dr hab. Jarosław Kupczak OP, Papieska Akademia Teologiczna w Krakowie) oraz Humanae vitae - spojrzenie małżonków (Bernadetta i Robert Nogajowie, Wyższa Szkoła Filozoficzno-Pedagogiczna Ignatianum w Krakowie). Materiały archiwalne dotyczące udziału kard. Karola Wojtyły oraz krakowskich teologów w przygotowaniu i recepcji encykliki Humanae vitae ukażą się w ramach serii Studia nad Myślą Jana Pawła II Papieskiej Akademii Teologicznej w Krakowie i Centrum Jana Pawła II „Nie lękajcie się”.

Sekcja Homiletyczna. Przewodniczącym sekcji jest ks. prof. zw. dr hab. Kazimierz Panuś. W roku sprawozdawczym 2008 kierownik sekcji wystąpił z kilkoma referatami upowszechniającymi problematykę homiletyczną. I tak: 28 lutego 2008 wygłosił wykład pt. „To paint the world with the colours of hope". Theological reflections na dorocznym posiedzeniu The Hope Theological Society w Liverpoolu. Podczas sesji naukowej Błogostawiony Wincenty Kadłubek $w$ 800-lecie sakry biskupiej zorganizowanej 3 listopada 2008 roku przez Polską Akademię Umiejętności, Archiwum Krakowskiej Kapituły Metropolitalnej i Opactwo Cystersów w Mogile wygłosił w auli PAU w Krakowie wykład nt. Bt. Wincenty Kadtubek $w$ kaznodziejstwie polskim (przeglą problematyki). Podczas konferencji naukowej Stowa, stowa, stowa... Refleksje o stowie 24 listopada 2008 roku zorganizowanej przez Instytut Teologiczny im. św. Jana Kantego w Bielsku-Białej i Katedrę Polonistyki Akademii Techniczno-Humanistycznej w Bielsku-Białej wygłosił wykład nt. Tajemnica stowa $i$ sztuka jego przekazu. Podczas konferencji naukowej Teologiczne refleksje po lekturze ksiażki Josepha Ratzingera - Benedykta XVI Jezus z Nazaretu zorganizowanej 3 grudnia 2008 przez Oddział w Radomiu wygłosił wykład nt. Inspiracje homiletyczne ksiażki Benedykta XVI.

Sekcja Socjologiczno-Pastoralna. Sekcja skupia dwudziestu naukowców z dziedziny socjologii, katolickiej nauki społecznej i teologii pastoralnej działających głównie w środowiskach naukowych Krakowa, Warszawy i Lublina. Pracami sekcji kieruje ks. dr Stefan Dobrzanowski. W roku sprawozdawczym sekcja zorganizowała jedno posiedzenie naukowe. Wykład nt. Czy rodzina ma przyszłość wygłosił członek sekcji prof. Franciszek Adamski. W ożywionej dyskusji zastanawiano się nad zagrożeniami i przyszłością rodziny. Członkowie sekcji brali także udział w licznych konferencjach oraz wygłaszali prelekcje popularnonaukowe w stowarzyszeniach i klubach katolickich. 
Sekcja Sztuki Sakralnej. Pracami sekcji kierował śp. ks. prof. dr hab. Zdzisław Kliś († 25 stycznia 2009). Z jego inicjatywy 21 listopada 2008 odbyła się konferencja naukowa pt. $Z$ dziejów kościoła św. Anny w Krakowie, w trakcie której wygłoszono następujące referaty: Archiwalia kolegiaty św. Anny w Archiwum Kapitulnym na Wawelu (ks. dr hab. Jacek Urban, prof. PAT), Duchowieństwo świętoańskie XVIII i XIX wieku (ks. dr hab. Jan Szczepaniak, prof. PAT), Św. Jan z Kęt i studzy Boży: bp Jan Pietraszko, Jerzy Ciesielski, dr Stanisław Kownacki (ks. infułat Władysław Gasidło), Legaty testamentowe na kościót św. Anny w Krakowie (1400-1530). Z krakowskich ksiag miejskich (dr Elżbieta Piwowarczyk), XV-wieczny kościót św. Anny w Krakowie. Próba rekonstrukcji (dr hab. Andrzej Włodarek, dr hab. Tomasz Węcławowicz), Pierwotny grób św. Jana Kantego (dr hab. Andrzej Włodarek), Restauracja kościoła św. Anny w Krakowie. Kontrowersja z końca XVI wieku (dr Paweł Pencakowski), Wybrane rzeźby i pomniki w kościele św. Anny w Krakowie (dr Józef Wroński), Złotnictwo ze skarbca kościoła św. Anny w Krakowie (mgr Jerzy Żmudziński), Tkaniny liturgiczne z zakrystii kościoła św. Anny w Krakowie (dr Beata Biedrońska-Słotowa) oraz Organy w kościele św. Anny w Krakowie (ks. dr Robert Tyrała).

SeKcJa Filozoficzna. Kierownikiem sekcji jest o. dr Piotr Jordan Śliwiński OFMCap. Sekcja nie przedstawiła sprawozdania.

Sekcja Teologi Życia Wewnętrznego. Kierownikiem sekcji od 24 września 2008 jest ks. dr hab. Wojciech Misztal, prof. PAT. Sekcja jest $\mathrm{w}$ trakcie reorganizacji.

Sekcja Pedagogiczno-Katechetyczna. Kierownikiem sekcji jest ks. prof. dr hab. Janusz Mastalski. W roku sprawozdawczym sekcja włączyła się w organizację kilku sympozjów. 15 stycznia 2008 brała udział w konferencji dotyczącej FAS (Płodowy Zespół Alkoholowy). 23 września został zorganizowany cykl wykładów i szkoleń dla samorządowców i nauczycieli pt. Powinności nauczycieli i samorządów wobec uczniów. Wymiar aksjologiczny. Największym przedsięwzięciem była współorganizacja Światowego Kongresu Juliana Aleksandrowicza, który odbył się w dniach 22-24 października 2008 w Krakowie. W kongresie uczestniczyli najwybitniejsi psychologowie, lekarze i pedagodzy z kraju i zagranicy. Dodatkowo sekcja zorganizowała spotkanie studyjne mające charakter panelu, na którym podjęto tematykę związaną z toksycznymi wymiarami współczesnej szkoły.

Sekcja Dogmatyczna. Kierownikiem sekcji jest ks. dr hab. Jan Żelazny. Sekcja zorganizowała w dniu 20 listopada 2008 konferencję naukową: Świętość a dobro. W jej trakcie wygłoszono następujące referaty: Świętość dana czy zadana $w$ świetle ideałów człowieka głoszonych $w$ starożytności (ks. dr hab. Arkadiusz Baron, PAT), Kościót jak wspólnota świętych (ks. prof. dr 
hab. Henryk Pietras SJ, Ignatianum) oraz Gnoza (zbawcza wiedza) i świętość (ks. prof. dr hab. Wincenty Myszor, UŚ).

Sekcja Misjologiczna. Pracami sekcji kieruje od 23 kwietnia 2008 ks. dr Grzegorz Wita. Członkowie sekcji kontynuowali comiesięczne spotkania w ramach seminariów otwartych, podczas których omawiane były aktualne zagadnienia realizacji misji Kościoła. W dniach 9-14 lutego 2008 członkowie sekcji (ks. prof. J. Górski i ks. dr G. Wita) uczestniczyli w Rzymie w spotkaniach i obradach zarządu Stowarzyszenia Misjologów Polskich. W roku 2008 sekcja wraz z Dziełem Misyjnym Archidiecezji Katowickiej realizowała projekt Solidarni z chrześcijanami w młodych Kościołach mający na celu wsparcie wspólnot chrześcijańskich na Bliskim Wschodzie, w Afryce i Ameryce Południowej. 8 czerwca 2008 odbył się VI Rajd Misyjny Dzieła Misyjnego Archidiecezji Katowickiej (Bielsko-Biała Szczyrk-Górka) współorganizowany przez członków sekcji. W dniach 1-4 sierpnia zorganizowane zostało Letnie Seminarium Misjologiczne w Hornych Lefantovcach (Słowacja). W dniach 17-23 sierpnia kierownik sekcji uczestniczył w Międzynarodowym Kongresie Misjologicznym IAMS w Balatonfured na Węgrzech. W sierpniu 2008 ks. prof. dr hab. Jan Górski przebywał z gościnnymi wykładami z misjologii w Instytucie Teologii Pastoralnej w Cochabamba (Boliwia). Członkowie sekcji wspierali też projekt pomocy medycznej archidiecezji katowickiej dla Wiejskich Ośrodków Zdrowia (RHC) w archidiecezji Lusaka w Zambii. Członkowie sekcji podejmowali działania na rzecz integracji środowiska misjologicznego poprzez ścisłą współpracę ze Stowarzyszeniem Misjologów Polskich oraz środowisk misyjnych i misjologicznych Kościoła w Polsce z Niepokalanowa, Krakowa i UKSW w Warszawie.

Sekcja Prawa Kanonicznego. Kierownikiem sekcji jest ks. dr Józef Rapacz. W roku sprawozdawczym zorganizowano 2 spotkania: 25 kwietnia 2008 nt. Kiedy malżeństwo jest nieważne? z referatami: Podstawowe tytuly nieważności matżeństwa (ks. dr Józef Rapacz) oraz Przestuchanie stron i świadków w postępowaniu o orzeczenie nieważności matżeństwa (ks. $\mathrm{dr}$ Stanisław Molendys); 14 listopada nt. Najczęstsze przyczyny nieważnego zawarcia matżeństwa z referatem Brak zdolności do podjęcia istotnych obowiązków matżeńskich (ks. dr Józef Rapacz). Spotkania odbywały się przy parafii Świętej Jadwigi Królowej w Krakowie.

Sercja Liturgiczna. Sekcję prowadzi ks. mgr lic. Stanisław Mieszczak SCJ. Podjęto prace nad integracją środowiska liturgistów. Włączono się w prace przygotowawcze kongresu Pueri Cantores w Nowym Sączu.

Oddzial w Katowicach. Pracami oddziału kieruje ks. dr Andrzej Nowicki. W roku sprawozdawczym odbyły się dwa zebrania. Pierwsze z nich miało miejsce dnia 13 czerwca 2008 w ramach konferencji pt. Innego Papie- 
ża nie znaliśmy poświęconej osobie sługi Bożego Jana Pawła II w związku z 25. rocznica jego pobytu w Katowicach-Muchowcu. W tym dniu zostały wygłoszone cztery referaty: Przyjaciel z rocznika formacji (ks. Franciszek Strauch), Świadectwo Muchowca 1983 (ks. Henryk Zganiacz), Ewangelia pracy - treść i znaczenie papieskiego orędzia (ks. dr Andrzej Suchoń) oraz Dorastanie z Janem Pawtem II (Krystyna Szmajduch). Członkowie Oddziału w Katowicach byli także współorganizatorami dni duchowości (razem ze Śląskim Seminarium Duchownym), które odbyły się w dniach 25-26 września w Wyższym Śląskim Seminarium Duchownym w Katowicach, pod hasłem: Powołani do świętości. W pierwszym dniu swoje referaty wygłosili: ks. prof. Thomas Noris, członek Międzynarodowej Komisji Teologicznej reprezentujący Saint Patrick's College, Maynooth (Świętość wedtug Nowego Testamentu), ks. dr hab. Marek Chmielewski, prof. KUL (Świętość w dziejach Kościoła), s. Maria Hilaria Hatko SSND (Jesteśmy na drodze proponowanej przez Ewangelię) oraz Zbigniew Nosowski, redaktor naczelny miesięcznika „Więź” (Świętość ludzi świeckich: życie jako powołanie). W drugim dniu swoją refleksją w aspekcie wyżej określonego tematu podzielili się ponownie ks. prof. Thomas Noris (Świętość i kapłaństwo stużebne) oraz o. dr Piotr Jordan Śliwiński OFMCap z Uniwersytetu Jagiellońskiego (Świętość w postmodernizmie). Po każdym z wykładów miała miejsce ożywiona dyskusja, w której uczestniczyli członkowie katowickiego oddziału towarzystwa, obecni na spotkaniu studenci Wydziału Teologicznego Uniwersytetu Śląskiego oraz alumni Wyższego Śląskiego Seminarium Duchownego w Katowicach. Zebrania katowickiej sekcji PTT odbywają się najczęściej w gmachu Wyższego Śląskiego Seminarium Duchownego.

Oddzią w Częstochowie. Pracami oddziału kieruje ks. dr Jerzy Bielecki. W roku sprawozdawczym odbyły się 3 zebrania zarządu oddziału i zorganizowano dwa posiedzenia naukowe: 5 kwietnia 2008 odbyło się sympozjum nt. Prawdziwe oblicze chrześcijańskiej nadziei z okazji ukazania się encykliki Spe salvi. Wygłoszono wówczas 3 referaty: W nadziei jesteśmy zbawieni (ks. prof. dr hab. Antoni Tronina), Eschatologiczny wymiar chrześcijańskiej nadziei (ks. dr Jerzy Bielecki), Modlitwa jako szkoła nadziei (ks. prof. dr hab. Stanisław Urbański). Natomiast w czerwcu 2008 roku ks. dr hab. Zdzisław Małecki na spotkaniu członków towarzystwa wygłosił referat Biblioteka $z$ Nag Hammadi.

Oddziat w Przemyślu. Pracami oddziału kieruje ks. prof. dr hab. Marian Wolicki. W okresie sprawozdawczym odbyły się dwa spotkania: 23 maja 2008 z referatem ks. dra hab. Jana Twardego nt. Antropologiczne źródta kazań oraz 23 października z referatem kierownika oddziału nt. Jaki typ filozofii proponuje Ojciec Święty w encyklice „Fides et ratio” wygłoszonym 
podczas sesji naukowej z okazji 10. rocznicy encykliki Fides et ratio pt. Rozumna wiara - wierzący rozum. Spotkaniom towarzyszyła ożywiona dyskusja.

OdDZial w Kalwari ZeBrzydowsKies. Kieruje nim o. dr Romuald Kośla OFM. W okresie sprawozdawczym Oddział w Kalwarii Zebrzydowskiej działający przy Wyższym Seminarium Duchownym Ojców Bernardynów zorganizował cztery spotkania. 11 lutego odbyła się sesja naukowa $Z$ dziejów duszpasterstwa zakonnego wśród Polonii na świecie. W 50. rocznicę powstania Polskiego Ośrodka Katolickiego Ojców Bernardynów w Martin Coronado (1957-2007). Kolejne spotkanie miało miejsce 18 kwietnia 2008 z referatem dr Wandy Półtawskiej nt. Tożsamość kobiety. Trzecie spotkanie oddziału 8 listopada połączone było $\mathrm{z}$ inauguracją roku akademickiego. W jego ramach o. dr Feliks St. Marchewka OFM wygłosił referat na temat: Koncepcja nieskończoności u Arystotelesa. 29 listopada odbyła się sesja naukowa zorganizowana wraz z Ośrodkiem Studiów Franciszkańskich w Krakowie z racji 700-lecia śmierci bł. Jana Dunsa Szkota, patrona WSD w Kalwarii Zebrzydowskiej. Wygłoszono wówczas referaty: Krytyczna biografia bt. Jana Dunsa Szkota (o. dr hab. Benedykt Jacek Huculak OFM, Komisja Szkotystyczna, Rzym); Koncepcja nieskończoności u Jana Dunsa Szkota (o. dr Feliks Stanisław Marchewka OFM, Kalwaria Zebrzydowska); Echa chrystologii Jana Dunsa Szkota w studium o teologii odkupienia Międzynarodowej Komisji Teologicznej z 1995 roku (o. dr Romuald Henryk Kośla OFM); Aktualne zadania redakcyjne i wydawnicze Komisji Szkotystycznej w Rzymie (o. dr hab. Benedykt Jacek Huculak OFM, Komisja Szkotystyczna, Rzym).

Oddziat w TuchowiE. Kieruje nim o. dr Marek Kotyński CSsR. W roku sprawozdawczym nie przedstawiono sprawozdania.

OdDZIAL W KIELCACH. W związku z wyborem dotychczasowego kierownika oddziału na wiceprezesa towarzystwa nowym kierownikiem oddziału został ks. dr Paweł Borto. W roku sprawozdawczym odbyło się 7 spotkań skoncentrowanych wokół czterech podstawowych kierunków działalności: przygotowanie materiałów do kolejnej publikacji zbiorowej, zorganizowanie sesji naukowej, promocja wiedzy teologicznej poprzez organizowanie spotkań z zainteresowanymi tą tematyką i wygłaszanie prelekcji oraz dyskusji panelowej poświęconej analizie działalności naukowej członków oddziału kieleckiego i wydawanych przez nich artykułów, przygotowanie doktoratów i habilitacji. Spotkanie kwietniowe (11 IV) poświęcono formule i zawartości merytorycznej „Kieleckich Studiów Teologicznych”. Postanowiono przekazywać publikowane tam artykuły osądowi recenzentów zewnętrznych. Wielu członków oddziału kieleckiego uczestniczyło w międzynarodowej interdyscyplinarnej konferencji naukowej Dziedzictwo i teraźniejszość. Polsko-europejski dialog kultur (19-20 V 2008). Członko- 
wie oddziału podejmują dobrą współpracę z Instytutem Filologii Polskiej Uniwersytetu Humanistyczno-Przyrodniczego im. Jana Kochanowskiego. Optymizmem napawa fakt rozwoju oddziału poprzez włączenie się w jego prace nowych członków.

Oddziat w SANDOMIERzU. Kierownikiem oddziału działającego przy Instytucie Teologicznym im. bł. Wincentego Kadłubka w Sandomierzu jest ks. prof. dr hab. Jan Zimny. W okresie sprawozdawczym zorganizowano 4 konferencje naukowe: III Sandomierskie Dni Cyrylometodiańskie - międzynarodowa sesja naukowa (Sandomierz, 14 lutego 2008); III Międzynarodowa Konferencja Naukowa Pomoc dziecku i rodzinie w sytuacji kryzysowej-osiagnięcia, problemy, perspektywy (Stalowa Wola, 17 kwietnia), sympozjum międzynarodowe Założenia kształceniowe $i$ wychowawcze w pedagogice katolickiej jako nowej formie propozycji edukacyjnej (Sandomierz, 14 maja). W ramach tej konferencji referaty wygłosili członkowie oddziału: bp prof. Andrzej Dzięga - Relacje między pedagogika katolicka a katechetyka w relacjach historycznych, ks. prof. Jan Zimny - Założenia dydaktyki i pedagogii w pedagogice katolickiej i ks. dr hab. Roman Bogusław Sieroń - Model wychowania katolickiego w Piśmie Świętym. Czwarta konferencja naukowa podjęła temat: Św. Pawet Apostot jako pedagog chrześcijański (Sandomierz, 4 czerwca).

Oprócz udziału w konferencjach naukowych organizowanych w Sandomierzu i Stalowej Woli członkowie oddziału sandomierskiego wygłaszali również referaty w konferencjach zagranicznych. I tak kierownik oddziału ks. Jan Zimny wygłosił 3 referaty na Ukrainie: Pedagogika katolicka jako nowa forma propozycji edukacyjnej (referat wygłoszony w Państwowym Instytucie Doskonalenia Nauczycieli, Winnica, 20 maja 2008), Wartość $i$ znaczenie Internetu jako formy edukacyjnej i pedagogii w procesie formacyjnym młodego człowieka (referat wygłoszony podczas VIII Międzynarodowej Konferencji Naukowo-Praktycznej, Państwowy Uniwersytet Pedagogiczny im. Michaiła Kociubińskiego, Winnica, 21 maja), Szkoła miejscem tworzenia kultury w duchu chrześcijańskim (referat wygłoszony podczas Międzynarodowej Konferencji Naukowo-Praktycznej Profesjonalna szkoła w systemie oświaty państwowej, Zaporoże, 1-3 października 2008). Podobnie ks. dr hab. Roman Bogusław Sieroń wygłosił 4 referaty na Ukrainie: Rola Biblii w odkrywaniu istoty $i$ źródet kultury Stowian na przykładzie narodów polskiego i ukraińskiego (Państwowy Instytut Doskonalenia Nauczycieli, Winnica, 20 maja 2008), Wykorzystanie nowych technologii komunikacyjnych $w$ proforystycznym wymiarze pedagogiki katolickiej na przykładzie działalności Polskiego Dzieła Biblijnego im. Jana Pawta II (referat wygłoszony podczas VIII Międzynarodowej Konferencji Naukowo-Praktycznej, Państwowy Uniwersytet Pedagogiczny im. 
Michaiła Kociubińskiego, Winnica, 21 maja), Orędzie pedagogiczne św. Pawła Apostoła dla wspótczesnych wychowawców. Refleksja teologiczno-pedagogiczna w Roku Pawta - Świętego Wschodu i Zachodu (Państwowy Uniwersytet Pedagogiczny im. Michaiła Kociubińskiego, Winnica, 22 maja) oraz Etyka pedagogiczna w wychowaniu moralno-duchowym św. Pawła Apostoła (referat wygłoszony podczas Międzynarodowej Konferencji Naukowo-Praktycznej Profesjonalna szkoła w systemie oświaty państwowej, Zaporoże, 1-3 października). Referat Rola estetyki w procesie wychowania wygłosił w Zaporożu także członek oddziału Jerzy Dąbek podczas Międzynarodowej Konferencji Naukowo-Praktycznej Profesjonalna szkoła w systemie oświaty państwowej, 1-3 października. Członkowie oddziału sandomierskiego prowadzili także działalność wydawniczą, czego owocem jest 11 pozycji książkowych wydanych w roku sprawozdawczym. W prace oddziału żywo angażował się biskup sandomierski prof. dr hab. Andrzej Dzięga.

OddzIAE w TARnOwIE. Kierownikiem oddziału jest ks. dr hab. Janusz Królikowski, prof. PAT. W roku sprawozdawczym oddział w Tarnowie kontynuował prace podjęte w roku 2007. Wśród zakończonych prac warto odnotować obszerną publikację poświęconą dwudziestej rocznicy pobytu papieża Jana Pawła II w Tarnowie (1987). Ostateczny kształt tej pracy jest efektem zaangażowania prawie wszystkich członków oddziału tarnowskiego. Wśród przygotowanych publikacji członków oddziału należy odnotować dwa kolejne tomy promowanej przez oddział serii Theologumena (3 i 4), które powstały jako rezultat prac członków. Przygotowano i wygłoszono dwa referaty związane z Rokiem św. Pawła. Jesienią roku 2008 odbyły się spotkania zarządu oddziału, podczas których poruszono kierunki prac oddziału, sprawę włączenia się w konferencje naukowe organizowane przez członków oddziału, kwestie strony internetowej. Z okazji 5. rocznicy śmierci ks. prof. Jana Dudziaka w listopadzie 2008 przygotowane zostało okolicznościowe wspomnienie, w czasie którego zaprezentowano osobę i dorobek zmarłego.

Oddziat w Rzeszowie. Kierownikiem oddziału jest ks. dr hab. Andrzej Garbarz, prof. Uniwersytetu Rzeszowskiego. Znaczacym dokonaniem oddziału było zorganizowanie w Instytucie TeologicznoPastoralnym w Rzeszowie wespół ze Stowarzyszeniem Civitas Christiana międzynarodowej konferencji naukowej Kultura chrześcijańska a wspólnoty lokalne i regionalne w Europie Środkowo-Wschodniej (3-4 grudnia 2008). W konferencji wzięli udział przedstawiciele Civitas Christiana niemal ze wszystkich ośrodków w Polsce oraz goście z zagranicy: z Odessy (Ukraina) i z Koszyc (Słowacja). Materiały pokonferencyjne zostaną wkrótce opublikowane. Ponadto członkowie oddziału rzeszowskiego uczestniczyli w wielu innych konferencjach organizowanych przez Wyższe Seminarium Duchow- 
ne, Uniwersytet Rzeszowski oraz Wyższą Szkołę Informatyki i Zarządzania. Opublikowali też szereg artykułów w czasopismach teologicznych oraz angażowali się w różnorodną działalność naukową i duszpasterską, m.in. prowadząc audycje w Katolickim Radiu VIA.

Oddziat w Bielsku-BiaŁeJ. Kierownikiem oddziału jest ks. prof. zw. dr hab. Tadeusz Borutka. Oddział istnieje od 26 września 2006 roku i liczy aktualnie 41 członków. W roku sprawozdawczym 2008 odbyły się dwa spotkania towarzystwa w siedzibie Instytutu Teologicznego im. św. Jana Kantego w Bielsku-Białej: 8 stycznia 2008 roku spotkanie opłatkowe dla członków Polskiego Towarzystwa Teologicznego i środowiska akademickiego Podbeskidzia z udziałem bpa Tadeusza Rakoczego oraz 16 grudnia 2008 roku z wykładem Koncepcja osoby a trynitarność Kościoła ks. dra Jana Duraja. Członkowie oddziału bielskiego wzięli również udział w odbywającej się dniach 24-25 listopada 2008 roku sesji naukowej na temat Słowa, słowa, słowa... organizowanej wspólnie z Katedrą Polonistyki Akademii Techniczno-Humanistycznej w Bielsku-Białej.

Oddzią w Radomiu. Kierownikiem oddziału jest ks. dr Dariusz Zbigniew Skrok. Oddział został powołany 25 września 2007 roku. Mimo tak krótkiego czasu liczy już 42 członków. Najważniejszym wydarzeniem w roku sprawozdawczym była konferencja naukowa w dniu 3 grudnia 2008 nt. Teologiczne refleksje po lekturze książki Josepha Ratzingera - Benedykta XVI „Jezus z Nazaretu”.

SEKCJA WydAwnicZa prowadząca Wydawnictwo UNUM w roku 2008 wydała cztery numery kwartalnika „Ruch Biblijny i Liturgiczny”, który otrzymał na rok 2008 dofinansowanie Ministra Nauki i Szkolnictwa Wyższego, opublikowała 25 publikacji książkowych, w tym 4 publikacje pokonferencyjne dofinansowane przez Ministra Nauki i Szkolnictwa Wyższego. Kierownik Sekcji Wydawniczej sporządził raporty z realizacji zadań finansowanych ze środków na działalność wspomagającą badania w roku 2008 oraz wnioski o finansowanie działalności wspomagającej badania w roku 2009, które zostały przez zarząd złożone w Ministerstwie Nauki i Szkolnictwa Wyższego. Ponadto Sekcja Wydawnicza prowadzi stronę internetową towarzystwa.

\section{Uwagi końcowe}

Do najważniejszych dokonań zarządu Polskiego Towarzystwa Teologicznego w Krakowie w roku sprawozdawczym należy zaliczyć nawiązanie bliskiej współpracy z The Hope Theological Society w Liverpoolu i obecność prezesa na walnym zgromadzeniu tego towarzystwa. Ważnym 
wydarzeniem dla Polskiego Towarzystwa Teologicznego było zorganizowanie i przeprowadzenie dwóch konferencji naukowych. Pierwsza z nich pt. Przebaczamy i prosimy o przebaczenie poświęcona była podstawom teologicznego nauczania o przebaczeniu i pojednaniu. Uczestnicy sesji rozważali, jakie znaczenie dla współczesnego Polaka mają te wartości, których horyzont wyznaczają słowa biskupów polskich do episkopatu niemieckiego „Przebaczamy i prosimy o przebaczenie” oraz podejmowana przez państwo lustracja. Konferencja ta była pierwszą w trzyletnim programie badawczym towarzystwa nad zagadnieniem przebaczenia. Z kolei konferencja naukowa pt. Świętość a dobro spotkała się z dużym odzewem zarówno krakowian, jak i uczestników z innych ośrodków akademickich (Katolicki Uniwersytet Lubelski Jana Pawła II, Uniwersytet Śląski w Katowicach, Uniwersytet Adama Mickiewicza w Poznaniu). W swojej strukturze nawiązywała do sympozjonów organizowanych przez ks. prof. dra hab. Mariana Michalskiego i ks. prof. Edwarda Stańka.

Z uznaniem należy podkreślić ożywioną działalność oddziałów kieleckiego i sandomierskiego oraz sekcji biblijnej, teologii moralnej, misjologicznej i katechetyczno-pedagogicznej. W roku sprawozdawczym upowszechniła się też wiedza o naszym towarzystwie. Wyrazem tego może być sprawowanie honorowego patronatu nad Światowym Kongresem z okazji 100-lecia urodzin prof. Juliana Aleksandrowicza.

Należy jednak przyznać, iż organizowanie spotkań sekcyjnych niektórych sekcji nie zawsze spotykało się z szerokim odzewem, a posiedzenia nie gromadziły wielu osób.

Polskie Towarzystwo Teologiczne jest publicznym stowarzyszeniem wiernych, stąd zarząd na ręce Jego Eminencji Kardynała Stanisława Dziwisza oraz księży biskupów obecnych na walnym zebraniu składa serdeczne podziękowanie Konferencji Episkopatu Polski za troskę władz kościelnych o rozwój towarzystwa.

Zarząd dziękuje również wszystkim aktywnym członkom towarzystwa, którzy mimo wielorakich trudności czynią wszystko, aby działalność towarzystwa była kontynuowana i służyła dalszemu ubogaceniu polskiej myśli teologicznej. 